\title{
What value for pastoral livelihoods? An economic valuation of development alternatives for ephemeral wetlands in eastern Mauritania
}

\author{
Tara Shine ${ }^{1 *}$ and Beth Dunford ${ }^{2}$
}

\begin{abstract}
Pastoralism in Africa faces new challenges in an era of climate change, despite some improvements in policy and legislative frameworks as well as sporadic investment in pastoral development. There are concerns that pastoralism will not be sustainable in a climate-affected world, and this is seeing the return of policies to settle pastoralists and introduce modern cropping. Pastoralism is not yet understood as a specialisation to take advantage of instability and variability, and as a result, the trend has continued towards replacing pastoralism as a livelihood strategy rather than investing in it.

It is in this context that a study conducted in eastern Mauritania between 1999 and 2001 is presented here to demonstrate the economic value of ephemeral wetlands as multi-use resources for pastoralism, agriculture and biodiversity. At the time the study was conducted, governments and aid agencies across the Sahel were targeting wetlands as areas of high development potential to combat poverty and increase food security, converting them from multi-use resources to single-use, arable resources.

The study assesses the benefits of multiple-use systems compared to such single-use systems through economic valuation of production from the respective systems. Arable agriculture, livestock rearing and botanical and other natural resources are valued in the case of multiple-use systems and compared to arable production from single-use systems.

Multiple-use systems are found to out-perform single-use systems based on annual production values, when opportunity costs and the replacement costs of wetland resources are taken into account. The results also show that the multi-use systems are better adapted to a highly variable climate than single-use arable systems that are highly vulnerable to rainfall fluctuations. This has implications for production in a climate-constrained world where diversification and investment in pastoralism as a strategy for managing variability in drylands will be increasingly important.

The methodology used to value the wetlands remains relevant 15 years later, as governments, aid agencies and international organisations develop policies to guide pastoralism in dryland systems that are becoming increasingly variable and unpredictable in the face of climate change.
\end{abstract}

Keywords: Ephemeral wetlands, Economic value, Pastoralism, Multiple-use systems, Sustainable development, Climate change

\footnotetext{
* Correspondence: tara@tarashine.com

${ }^{1}$ Environment and Development Consultant, 127 The Meadows, Belgooly,

Co., Cork, Ireland

Full list of author information is available at the end of the article
} 


\section{Background}

Significant changes in climatic conditions have been observed in the Sahel and West Africa in recent years. This includes an overall rise in mean seasonal temperature from 1970 to 2006 of approximately $1{ }^{\circ} \mathrm{C}$, with a greater increase of between $1.5{ }^{\circ} \mathrm{C}$ and $2{ }^{\circ} \mathrm{C}$ observed in far eastern Chad and northern Mali and Mauritania (UNEP 2011). Pastoralists are mainly affected by changes in rainfall that influence the availability of shrubs, grasses and water sources for livestock. Large areas of Chad, Mali, Mauritania and Niger faced between six and ten drought seasons between 1982 and 2009 (UNEP 2011). Overall, the seasons are changing, with greater variability and increased frequency and severity of climate-related disasters, including floods and drought. Northern Africa is projected to become drier and hotter with climate change, and the provision of adequate water for livestock production could become more difficult, increasing production costs due to the need to extract water from boreholes (IPCC 2014).

The last decade has seen policy and legislative frameworks to address pastoralism adopted across the Sahel. The first pan-African policy on pastoralism was adopted by the African Union in 2010 and states that pastoral systems make a substantial contribution to both national and regional economies. It also describes pastoralism as the most sustainable economic activity in rangelands (African Union 2010).

At the national level, Niger adopted the Rural Code in 1993, which stipulated that pastoralists had priority rights to use natural resources in designated pastoral zones. In May 2010, a sector-specific law or Ordinance on pastoralism was passed, adding to texts that constitute the Rural Code and confirming the importance of pastoralism in Niger, while safeguarding mobility. A Pastoral Code was implemented in Mauritania in 2000, followed by Mali in 2001, Burkina Faso in 2003 and Chad in 2014. However, while provisions to support pastoralism are an improvement on past policies, much of the legislation is not sensitive to changes in climate and resource availability and as a result can inhibit the ability of pastoralists to adapt to the extremely unpredictable Sahelian environment (UNEP 2011).

These issues have been further compounded by the highly sectoral approach that is generally taken to the management of natural resources, which has resulted in competition and confusion between differing government institutions and fails to account for multiple uses of the land by livelihood groups such as agro-pastoralists (Hesse and Thébaud 2006).

In Mauritania, agriculture has not been performing well in recent decades. On average, the contribution of agriculture to gross domestic product (GDP) was $16.7 \%$ during the 1991 to 2008 period with crops representing
$3.7 \%$ and livestock $13 \%$. By 2014, agriculture continued to contribute just $16.9 \%$ of GDP despite employing $50 \%$ of the labour force (CIA 2015). Investment in the agriculture sector as a whole is low at only $6 \%$ of total public investment for the period 2012 to 2015 (World Bank 2013), and this includes both livestock and arable agriculture, with arable continuing to dominate the response to food insecurity (FAO 2015). Overall, there has been little or inadequate effort to support livestock in Mauritania, despite its importance in the rural economy (Islamic Development Bank 2011).

The African Union adoption of a policy framework for pastoralism in Africa in 2010 aimed to 'secure, protect and improve the lives, livelihoods and rights of African pastoralists' (African Union 2010). The implementation of this policy framework across the continent can be informed by studies such as the one presented in this paper which place a value on the use and sustainable management of wetland and other pastoral resources in dryland ecosystems.

In this paper, the livelihood value of ephemeral wetlands in eastern Mauritania, based on the multiple-use model that was practised from 1999 to 2001, is compared to the single-use intensive systems proposed at that time by development agencies. In the early 2000s, as now, the governments of most West African states were pursuing policies aimed at assuring food security and increasing levels of cereal production to feed growing populations (Bognounou et al. 1994; Shine 2001; African Union 2003; FAO 2015). Wetlands are typically viewed as having under-exploited potential and are targeted for agricultural development in the Sahel as elsewhere around the world (Adams 1992; Wetlands International 2015). Before implementing new systems of production and management of wetlands, economic valuation of current management systems is needed to evaluate the consequences of their conversion to alternative use to the local population and the national economy. As the impacts of climate change intensify, the resilience of multiple-use systems verus alternative systems also needs to be assessed.

\section{Study area}

This study was carried out from 1999 to 2001 in the region of Hodh El Gharbi in eastern Mauritania (Figure 1). It was part of the $\mathrm{PhD}$ research of both the first and second authors and was supported by Project GIRNEM, a natural resource management project led by the German Technical Cooperation (formerly GTZ, now GIZ). The purpose of the study was to understand the economic, social and environmental role and value of ephemeral wetlands in eastern Mauritania and propose management alternatives (Shine 2002). The region is characterised by highly variable rainfall, regular drought, poor infrastructure and isolation from major urban centres, 


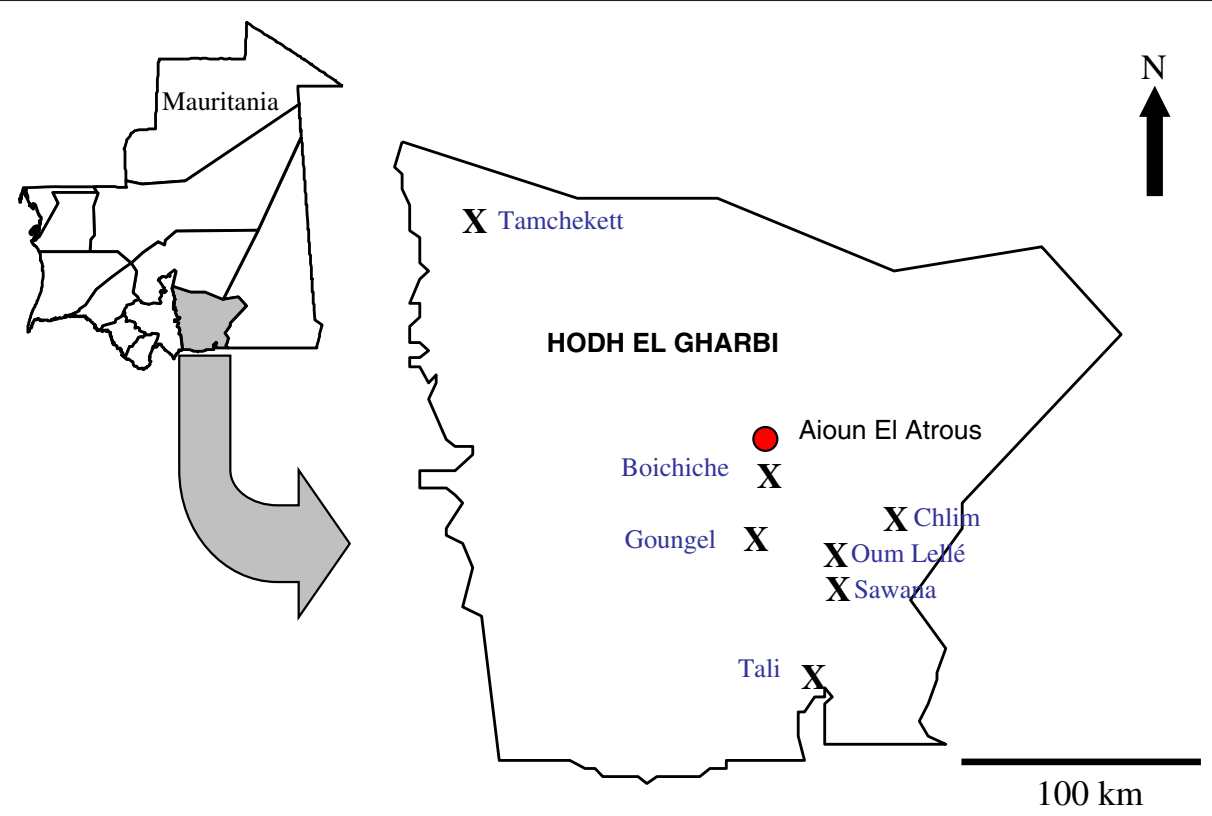

Figure 1 Map of Hodh El Gharbi showing the location of the seven case study wetland sites

including the national capital, Nouakchott. The region receives an average of $200 \mathrm{~mm}$ rainfall per year, rising to $400 \mathrm{~mm}$ in the extreme south of the region. Arable agriculture is practised most successfully in the better watered south and in some wetland depressions (at the time of the study, $8 \%$ of national sorghum production came from Hodh El Gharbi - SSA 2001).

Mobile, extensive livestock rearing dominated the region's economy in the late 1990 s with $80 \%$ of revenue created in the eastern regions coming from livestock rearing (MEMAU-AGRO 1999). Livestock rearing continues to be the most important economic activity in the region to this day, however a greater diversity of income sources now contributes to family incomes, including remittances (GRDR 2011). Livestock ownership remains a key determinant of the wealth and food security of households in the region. Statistics from the mid2000s confirm that mobile livestock rearing is still the dominant system in eastern Mauritania (Ibid.). In the late 1990s, $26 \%$ of the population of Hodh El Gharbi was nomadic, having fallen from over $80 \%$ in the 1960 s (ONS 1997). The trend towards increased sedentarisation continues today, due to social and environmental pressures, development interventions and national policy. Wetlands are ideal places to settle, as there is an ample supply of water, grazing, wild foods and construction materials. Unfortunately, no recent data is available on the trend towards sedentarisation as the 2013 census only contains results for the sedentary population, with results for the nomadic population still pending (Randall 2015).
Wetlands in eastern Mauritania are seasonal and highly variable landscape features (Shine 2002; GRDR 2011). They range in size from less than a hectare to 16,000 ha and in duration from several weeks to six months or more. Rainfall accumulates in shallow, clay-lined depressions during the wet season ${ }^{1}$ resulting in an abundance of life in the form of aquatic plants, fish, migrating birds, reptiles and mammals. The wet season occurs from July to October, the cold season from November to February, and the dry season from March to June. The wetlands are islands of biodiversity in an otherwise arid landscape and have higher densities of floral and faunal diversity than the surrounding drylands (Mullié and Brower 1994; Nickel 2001; Shine 2002). Several wetlands, including some of the sample sites, fulfil the criteria to qualify as wetlands of international importance under the Ramsar Convention (Shine 2002). Unfortunately, the ecological role of wetlands in drylands has not yet been sufficiently recognised (including as Ramsar sites) and has not been considered adequately when deciding development strategies.

\section{Methods}

This study values wetland resources under the multi-use system by awarding a monetary value to the production resulting from the pattern of resource exploitation practised in the late 1990s and that continues today. In the late 1990s and early 2000s, as today, there is pressure from the Mauritanian government and international aid agencies to develop wetlands for agriculture, so as to increase agricultural production. This highlights the need 
to develop methods to compare existing and proposed management systems to inform decision-making. A typical example of such development initiatives was underway at Tamourt Goungel, one of the sample wetlands, during the time the study took place.

At the time, a World Bank project, PGRNP (Projet de Gestion des Ressources Naturelles en Zone Pluviale) was in the process of fencing, draining and planting the entire wetland (Tamourt Goungel) with sorghum to increase the production of cereals with the aim of increasing food security. In order to do so, the traditional multiple-use system based on livestock rearing, arable agriculture, wild foods and forestry products was being cast aside in favour of transforming the wetland, enclosing it with a fence and introducing agricultural inputs, improved seeds, etc. ${ }^{2}$ Given that the central theme to all development interventions is the alleviation of poverty, development activities should result in improved livelihoods for the target population. This paper uses data from Tamourt Goungel and six other wetlands to calculate the economic benefits of multiple-use and single-use management of wetlands in eastern Mauritania, in order to determine which is of greater overall benefit to the local population.

Actual production recorded in the field for the agricultural year 1999/2000 is used to give a value for the seven sample wetlands under the existing multiple-use regimes. Where data are available, reference is also made to production in $2000 / 2001$. The alternative single-use agricultural system is considered in terms of input costs and opportunity costs. Both of these systems have economic benefits, and the relative merits of each is examined quantitatively in terms of revenue and qualitatively in terms of biodiversity value and resilience in the face of climatic variability. While two years' data give a mere snapshot of the productive capacity of the wetlands, especially as rainfall was above average in both years, it raises questions for policymakers about the development direction they have chosen.
The study was carried out in agricultural years 1999/ 2000 and 2000/2001 (an agricultural year runs from the beginning of the wet season in June-July to the end of the following dry season in May-June). Data were collected at seven sample wetlands, and reference is also made to Leweija, a cereal-producing wetland in the centre of the region. The names and some details of the sample wetlands are given in Table 1, and Figure 1 shows the location of the wetlands in Hodh El Gharbi. The duration refers to the number of months during which the wetlands held water. The marked differences in duration for the three years of data demonstrate the high level of variability these resources are subject to.

Data were collected in two ways:

1. Directly by the principal author working with field technicians and members of the local population engaged in agriculture, gardening and livestock rearing

2. From data collected on botanical resources through a socio-economic questionnaire carried out by both authors

\section{Arable agriculture}

Data on arable agriculture was collected using standardised forms from a sample of 20 flood recession fields per wetland. Data were also collected on 20 rain-fed fields if they were present in the vicinity of the wetland and were farmed by the same community. The data collected at each of the fields included:
i. Field size (ha)
ii. Crops grown
iii. Total yield
iv. Seasonality of activities

The total number of flood recession and rain-fed fields ${ }^{3}$ cultivated in the 1999/2000 and 2000/2001 per wetland community was recorded. In addition, the total

Table 1 Key characteristics of the sample wetlands

\begin{tabular}{llllll}
\hline Name & Local classification $^{\text {a }}$ & $\begin{array}{l}\text { Maximum area in } \\
1999 / 2000 \text { (ha) }\end{array}$ & $\begin{array}{l}\text { Duration in 1999/2000 } \\
\text { (months) }\end{array}$ & $\begin{array}{l}\text { Duration in 2000/2001 } \\
\text { (months) }\end{array}$ & $\begin{array}{l}\text { Duration in 2001/2002 } \\
\text { (months) }\end{array}$ \\
\hline Goungel & Tamourt & 638 & 12 & 12 & 6 \\
Boichiche & Tamourt & 204 & 6 & 5 & 3 \\
Tamchekett & Oued & 184 & 8 & 7 & 6 \\
Oum Lellé & Tamourt & 215 & 10 & 9 & 9 \\
Chlim & Tamourt & 606 & 9 & 3 & 5 \\
Sawana & Gâat & 835 & 9 & 12 & 3 \\
Tali & Tamourt & 966 & 12 & 12 & 2 \\
\hline
\end{tabular}

a Local terminology for wetland types: Tamourt - a place characterised by silty-clay soils where a pool is filled by rainwater and bordered by Acacia nilotica; Gâat - an expanse of water on flat ground or in a very shallow depression, often containing aquatic vegetation; Oued - also called a wadi in geographical literature. It is a desert watercourse, which is usually dry, and contains water only after heavy rainfall. Trees such as Acacia nilotica and Balanites aegyptiaca often flank them 
number of fields cultivated in ideal growing conditions was noted, although optimal conditions (maximum cultivable area) occur infrequently (approximately every five years or so).

A field technician collected harvest data from farmers in the local measure, known as mouds (1 moud sorghum $=4 \mathrm{~kg}$ ) to give a conservative estimate of annual yield. ${ }^{4}$ The yields are conservative as farmers are inclined to under-estimate the size of their harvest, in order to reduce the quantity of zakat (charity, one of the five pillars of Islam) they are obliged to pay. Annual production from agriculture is calculated from the average recorded yield per hectare and the number of hectares cultivated that year.

\section{Livestock rearing}

The basic information collected on pastoral production was the number of animals using the sample wetlands. A member of the local community counted the number of animals at the wetland on a particular day each week for as long as the wetland held water. These daily values are averaged per month to give a monthly mean. This monthly mean is the average number of animals using the wetland in a day, averaged over a calendar month.

When calculating annual production figures, one figure needs to be adopted to represent the number of animals using the wetland. Due to the seasonal variations in livestock numbers at the wetlands and the fact that the herds are very mobile, a mean daily value is not appropriate. Instead, the highest monthly mean value is used, as this eliminates the possibility of counting the same animal twice and gives a maximum daily number of animals using the wetlands. The value is conservative as some animals may use the wetlands at times other than during the month with the highest concentrations of animals. In summary, this method allows the calculation of a conservative production value, while limiting the risk of counting the same animal twice.

Cattle, camels, goats and sheep are included in these calculations as their meat and milk is consumed, and they are regularly traded at regional markets. Donkeys and horses also use the wetlands as watering points but, because their value is in terms of traction and transport, rather than milk and meat production which has a wellidentified price, they have been excluded from these calculations.

\section{Botanical and other natural resources}

A socio-economic survey was carried out at the sample wetlands by the authors in 1999/2000 (Dunford 2003). A total of 270 questionnaires were completed at 11 wetlands including the seven case study wetlands. The 270 respondents represent a sample from an unknown total population of wetland users in eastern Mauritania. ${ }^{5}$ Of these, 220 of the respondents are settled beside wetlands and 50 are nomads. This breakdown reflects the demographics of Hodh El Gharbi at that time where, in 1988, $26 \%$ of the population was nomadic and the remainder was settled or semi-settled (ONS 1997). Twenty-three percent of the respondents to the socio-economic questionnaire are nomads, which reflects the continuing trend to sedentarisation. Fifty-seven percent of the respondents are White Moor, and $43 \%$ are Haratine or Black Moor. ${ }^{6}$ This sample is under-representative of Black Moors who make up a slight majority in Hodh El Gharbi.

The socio-economic survey sampled 20 respondents per village, using cluster sampling to select the households to be interviewed (Dunford 2003). Sampling cards were used to assure representation of all sectors of society (women 18 to 34 , women $35+$, men 18 to 34 , men $35+$ ). In the case of the nomadic population, which is more mobile and difficult to locate, snowball sampling was used to find respondents based on recommendations from one nomadic camp to where to find the next.

Additional information was collected on the use of botanical resources through informal contact with women in the field. Women and children are the primary collectors of botanical resources. Supporting information came from published works (Leriche 1953; von Maydell 1992; ould Abderrezagh 1999).

Average market prices in 1999 are used to value production from the seven case study wetlands. This average price is based on data collected at the market in Aioun throughout 1999 by Project GIRNEM. ${ }^{7}$ Prices of livestock, milk, vegetables, grain and botanical and other natural resources (e.g. clay) were recorded on a weekly basis by the author in collaboration with the staff of Project GIRNEM. Market value in 1999 is the value used throughout this study to calculate production value.

\section{Results}

Economic valuation of multiple-use systems

Wetlands are generally under-valued resources, viewed as wastelands or areas in need of conversion to a more productive use. Economic valuation is an important tool in managing wetland resources, as it allows the current value of the wetland (which is often underestimated - Adger and Luttrell 2000) to be compared with the potential value after investment and development have taken place. Putting a value on the resources and functions performed by a wetland allows a more informed approach to their future management. Similar approaches are now being employed to calculate the total economic value (TEV) of pastoral resources (Hesse and MacGregor 2009).

Annual production is used to calculate the value of wetland resources. Production is calculated based on the yields of flood recession agriculture, off-take from 
livestock herds, milk production and the added value of forestry products and wild foods (referred to collectively as botanical resources). No attempt is made to calculate a monetary value for biodiversity; instead, reference is made to data on biodiversity value presented in Shine (2002). Aesthetic, recreational and hydrological functions of the wetlands are not included in this assessment as they are beyond the scope of the study.

\section{Arable agriculture}

Data were collected on flood recession and rain-fed agriculture at the seven case study wetlands. Sorghum is the main cereal grown in flood recession conditions while both millet and sorghum are grown in rain-fed fields. Only production from flood recession agriculture is used to value production from the wetland depression, since rain-fed farming does not depend on the wetland resource. Data on vegetable production are also included as the activity is dependent on the wells associated with shallow aquifers in wetland depressions.

Oum Lellé and Tamchekett are not used for flood recession agriculture and will therefore be absent from this discussion of arable agriculture. Leweija, a wetland devoted to agriculture in Hodh El Gharbi, is included to give further insights into the use of wetlands for agriculture.

\section{Areas devoted to flood recession agriculture}

The number of fields cultivated in the wetland depressions depends on the balance between too much and too little water. Too much water causes a delay in planting while the farmers wait for the water to subside. Too long a delay in planting increases the risk of crop failure due to high temperatures and hot winds at the end of the growing season.

There is a great deal of variation in the cultivated area from year to year as a result of variations in rainfall (Table 2). Too much water suppressed cultivation in Leweija in $1999 / 2000$ and Tali in 2000/2001, while too little water prohibited the growing of crops in Sawana and Chlim in 2000/2001. The high levels of inter-annual variability in rainfall make agriculture a high-risk activity in all but the southern fringes of eastern Mauritania.

\section{Agricultural production 1999/2000}

Actual yields were recorded in the field in 1999/2000 to give average yields per hectare for flood recession agriculture at five of the case study wetlands and Leweija (Table 3). The highest yielding wetlands are Gâats Sawana and Leweija, which are the only areas producing the average regional yield of $0.63 \mathrm{t} /$ ha for flood recession agriculture (Bureau Statistiques Agricoles 1999).

Sorghum sold for between 50 and $80 \mathrm{UM} / \mathrm{kg}$ on the market in Aioun in 1999/2000, with variations in price due to quality, supply and time of year. Due to variations in price throughout the year, a median figure (65 UM) is taken to represent the average price paid per kilo on the market in Aioun in 1999/2000.

The highest earning wetlands in terms of arable production are Leweija and Sawana, although Sawana's revenue fell from over 52 million UM in 1999/2000 to zero in 2000/2001 (due to the lack of rainfall at the site), clearly demonstrating the importance of diversifying revenue-creating activities (Table 3). The lowest earners in 1999/2000 were Tali, Chlim and Boichiche, with attention in Tali being turned to rain-fed agriculture due to extensive and prolonged flooding, while Chlim and Boichiche depended equally on rain-fed and flood recession agriculture as sources of revenue. Chlim, Sawana and Tali had zero revenue from agriculture in 2000/2001 (again due to a lack of rainfall) indicating the unreliability of flood recession agriculture as a single livelihood strategy.

\section{Vegetable gardening}

Vegetable gardening was a relatively new agricultural activity in Hodh El Gharbi, introduced by development projects as an additional source of revenue for settled communities. Vegetables generally earn a higher price per kilo than sorghum and, although labour input due to irrigation tends to be high, surveillance is not as intensive as in sorghum fields. This makes vegetable gardening an ideal supplementary activity where adequate water is available.

Table 2 Areas cultivated under flood recession agriculture at seven wetlands showing the maximum possible cultivated area and actual areas in 1999/2000 and 2000/2001

\begin{tabular}{|c|c|c|c|c|c|c|c|}
\hline Wetland & $\begin{array}{l}\text { Max no. } \\
\text { of fields }\end{array}$ & $\begin{array}{l}\text { Average field } \\
\text { size (ha) }\end{array}$ & $\begin{array}{l}\text { Max cultivatable } \\
\text { area (ha) }\end{array}$ & $\begin{array}{l}\text { No. of fields cultivated } \\
1999 / 2000\end{array}$ & $\begin{array}{l}\text { Area cultivated } \\
\text { 1999/2000 (ha) }\end{array}$ & $\begin{array}{l}\text { No. of fields cultivated } \\
2000 / 2001\end{array}$ & $\begin{array}{l}\text { Area cultivated } \\
2000 / 2001 \text { (ha) }\end{array}$ \\
\hline Boichiche & 60 & 1.17 & 70 & 32 & 37 & 37 & 43 \\
\hline Tali & 200 & 1.28 & 256 & 3 & 4 & 0 & 0 \\
\hline Sawana & 700 & 2.65 & 1,855 & 180 & 477 & 0 & 0 \\
\hline Chlim & 75 & 1.66 & 125 & 9 & 15 & 0 & 0 \\
\hline Goungel & 300 & 2.75 & 825 & 50 & 138 & 39 & 107 \\
\hline Leweija & 3,000 & 0.68 & 2,040 & 250 & 170 & 500 & 340 \\
\hline
\end{tabular}


Table 3 Revenue from flood recession cultivation of sorghum at six wetlands in 1999/2000 and 2000/2001 (based on 1999 market prices, in UM) ${ }^{8}$

\begin{tabular}{lcll}
\hline Wetland & $\begin{array}{l}\text { Yield per hectare } \\
\text { (t/ha) Flood recession } \\
\text { agriculture }\end{array}$ & $\begin{array}{l}\text { Revenue } \\
\text { 1999/2000 (UM) } \\
\text { Flood recession }\end{array}$ & $\begin{array}{l}\text { Revenue } \\
\text { 2000/2001 (UM) } \\
\text { Flood recession }\end{array}$ \\
\hline Boichiche & 0.304 & 365,560 & 427,705 \\
Tali & 0.276 & 79,040 & 0 \\
Sawana & 1.685 & $52,243,425$ & 0 \\
Leweija & 0.392 & $30,177,550$ & $60,355,100$ \\
Chlim & 0.152 & 269,100 & 0 \\
Goungel & 2.731 & $3,516,240$ & $2,732,730$ \\
\hline
\end{tabular}

When the revenues created per hectare from vegetable gardening and flood recession agriculture are compared, it becomes clear that vegetable gardening is a highly lucrative activity on small land holdings (Table 4). However, the potential to expand this activity is limited by the short growing season (winter months only), little local demand for produce (vegetables do not traditionally feature in the local diet), long distances to large urban markets and poor infrastructure.

\section{Pastoral production}

Mobile, extensive livestock rearing allows best use of variable resources, given their fluctuations over space and time, such as wetlands in an arid environment. In the wet season, herders use surface water held in temporary wetlands scattered across the northern Sahel to water their animals, while they benefit from protein-rich pasture (Breman and de Wit 1983). Each wetland provides access to around 45,000 ha of pasture, and without them, pastureland would go unexploited as the construction of wells and boreholes is not feasible in all areas (OECD/CILSS 1987; McCracken 2000).

An inventory of 244 wetlands in eastern Mauritania revealed that $97 \%$ of the wetlands are used for watering livestock (Shine 2002). All seven of the case study wetlands are used to water livestock and are included in this valuation.

\section{Methods for valuing pastoral resources}

Water and pasture are difficult commodities to quantify and value, so alternative methods are needed. Calculating the total value of the animals drinking at a wetland (based on wholesale animal prices) is a straightforward procedure but sheds little light on the annual productive value of the wetland. Annual productive value is defined here as the revenue created from the sale of marketable pastoral commodities over one year, i.e. meat and milk. While pastoral production also takes into account offspring and annual weight gain, these factors do not constitute a marketable product over a one-year period. Camels, cattle, goats and sheep are included in calculations of annual production. Horses and donkeys which are used for traction are excluded from this study.

\section{Numbers of animals using the case study wetlands}

Data on the mean monthly number of animals using the case study wetlands allow the detection of seasonal variations in wetland use and analysis of relative importance of the different wetlands for the livestock-rearing sector (Figure 2). Wetlands regularly hosting more than 10,000 animals are Tali, Oum Lellé and Goungel. All of the other study sites are important watering holes for animals when surface water is present, with daily counts ranging from hundreds to thousands depending on water availability.

\section{Off-take}

A proportion of the animals of a herd is sold and consumed each year and the live animal or the meat produced has a monetary value. Studies conducted at abattoirs in the capital, Nouakchott, have resulted in figures for the rate of exploitation of animal herds in Mauritania (Table 5). A large majority of the animals produced in eastern Mauritania are transported by road to Nouakchott to be sold, so figures from the Nouakchott abattoirs are applicable to livestock in the eastern regions (GIRNEM 1999). These figures are also consistent with figures for Africa and the Sahel in particular (Dahl and Hjort 1976).

Table 4 Comparison of earnings per hectare from flood recession cultivation of sorghum and vegetable gardening (based on UM market prices in 1999)

\begin{tabular}{lllllll}
\hline 1999/2000 & $\begin{array}{l}\text { Earnings from vegetable } \\
\text { production }\end{array}$ & $\begin{array}{l}\text { Earnings from flood } \\
\text { recession sorghum }\end{array}$ & $\begin{array}{l}\text { Area of vegetable } \\
\text { cultivation }\end{array}$ & $\begin{array}{l}\text { Area of flood recession } \\
\text { sorghum cultivation }\end{array}$ & $\begin{array}{l}\text { Production per } \\
\text { hectare of vegetables }\end{array}$ & $\begin{array}{l}\text { Production per } \\
\text { hectare of sorghum }\end{array}$ \\
\hline Wetland & UM & UM & ha & ha & UM/ha & UM/ha \\
Goungel & 235,000 & $3,516,240$ & 0.36 & 138 & 652,778 & 25,480 \\
Tali & 162,400 & 79,040 & 0.78 & 4 & 208,205 & 19,760 \\
Sawana & 0 & $52,243,425$ & 0 & 477 & 0 & 109,525 \\
Chlim & 23,600 & 269,100 & 0.33 & 15 & 71,515 & 17,940 \\
Boichiche & 30,000 & 365,560 & 1.15 & 37 & 26,087 & 9,880 \\
\hline
\end{tabular}




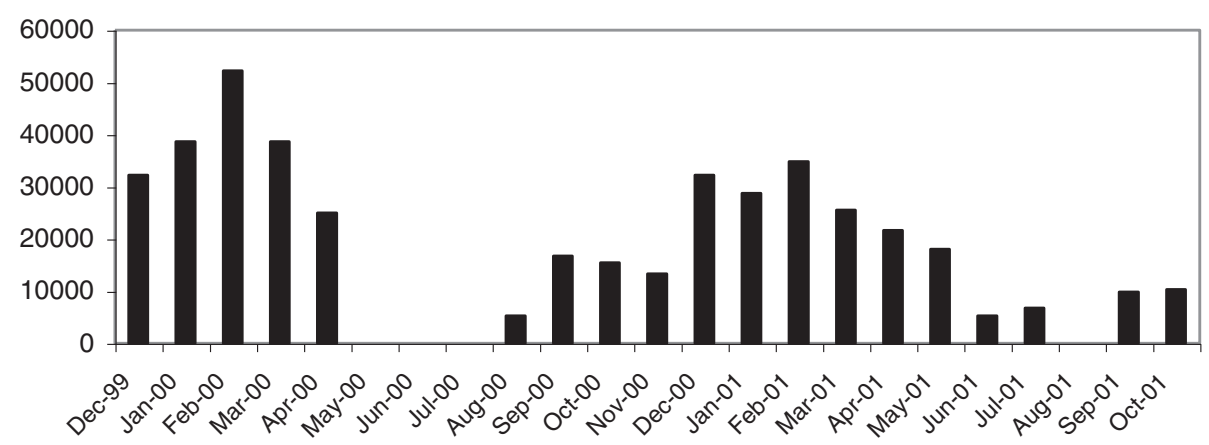

Figure 2 Total numbers of animals counted at seven wetlands from December 1999 to October 2001

Using the annual exploitation rates presented in Table 5 and wholesale market prices recorded in Aioun in 1999, a value for annual off-take can be calculated using the following formula for each type of herd:

$$
\begin{aligned}
\text { No. of animals } & \times \text { annual live off-take } \\
& \times \text { wholesale animal price }(U M) \\
& =\text { value of annual off-take }
\end{aligned}
$$

\section{Milk production}

The supply of milk to herders and their families throughout the year has a considerable monetary and nutritional value. In order to assess the milk-producing capabilities of a herd, we need to know something about herd composition. Efforts have been made to quantify the composition of cattle herds in Mauritania (Ould Cheikh 1986), and similar figures are available for camels, sheep and goats based on research from extensive systems in Africa (Dahl and Hjort 1976). Table 6 indicates expected proportions of females and lactating females in extensive herds in Mauritania.

Milk production per lactating female animal in Mauritania is known from studies conducted by Ould Cheikh (1986) and the Office National de la Statistique (1995). These figures and the average price of milk on the market in Aioun in 1999 are used to calculate the value of annual milk production per herd (Table 7).

\begin{tabular}{|c|c|c|c|c|}
\hline $\begin{array}{l}\text { Domestic } \\
\text { animal }\end{array}$ & $\begin{array}{l}\text { Exploitation } \\
\text { rate (\%) }\end{array}$ & $\begin{array}{l}\text { Average } \\
\text { carcase } \\
\text { weight }(\mathrm{kg})\end{array}$ & $\begin{array}{l}\text { Wholesale } \\
\text { animal price } \\
\text { UM (1998) }\end{array}$ & $\begin{array}{l}\text { Meat prices } \\
\text { Aioun (UM } \\
\text { kg 1998) }\end{array}$ \\
\hline Cattle & 10 & 150 & 42.000 & 290 \\
\hline Camels & 9 & 180 & 40.000 & 290 \\
\hline Sheep and goats & 25 & 15 & 9.000 & 450 \\
\hline
\end{tabular}

Table 5 Off-take rates of animals in Mauritania in 1998 (MDRE/ BDPA-SCETAGRI 1992; Van Lancker 1999)

${ }^{a}$ Average market price for a live animal over a one-year period (MDRE/GTZ 1998; McCracken 2000)

\section{Total pastoral production}

The month with the highest number of animals in $1999 / 2000$ is used to give a conservative value of the wetland's annual production. ${ }^{9}$ Values for off-take and milk production in $1999 / 2000$ and 2000/2001 were used to calculate total pastoral production. Tali and Oum Lellé had the highest values in both years (Table 7).

\section{Forestry products, wild foods and other botanical and natural resources}

Forestry products, wild foods and medicinal plants are collected for home use and for sale. Those of lower status in society rely more heavily on the collection of these products for earning cash (Dunford 2003). The collection of these products is particularly important in drought years when wild foods are used to supplement cultivated cereals and forestry products are sold to supplement family income (Dunford 2003). The primary forest products and wild foods (botanical resources) used in eastern Mauritania were identified from the socio-economic survey and contact with the local population in the field. These include the fruit of Ziziphus mauritiana (jib jib), the seed pods of Acacia nilotica (salaha), Gum Arabic, the grains of Echinochloa colona $(A z)$, water lily tubers - Nymphaea lotus (Tilba) and the fruit of Balanites aegyptiaca.

Table 6 Adult females and lactating females as a proportion of total herds (adapted from Dahl and Hjort 1976)

\begin{tabular}{lll}
\hline Herd type & $\begin{array}{l}\text { Adult females as \% } \\
\text { of total herd }\end{array}$ & $\begin{array}{l}\text { Lactating females as \% } \\
\text { of total herd }\end{array}$ \\
\hline Cattle & 41 & 15 \\
Camels & 34 & 17 \\
Goats & 35 & 13 \\
Sheep & 39 & 16 \\
\hline
\end{tabular}


Table 7 Total pastoral value of the seven study wetlands in 1999/2000 based on 1999 market prices

\begin{tabular}{lllll}
\hline Wetland & $\begin{array}{l}\text { Off-take production } \\
1999 / 2000(U M)\end{array}$ & $\begin{array}{l}\text { Milk production } \\
1999 / 2000(U M)\end{array}$ & $\begin{array}{l}\text { Total pastoral } \\
\text { production (UM) }\end{array}$ & $\begin{array}{l}\text { Total pastoral } \\
\text { production Euros (€) }\end{array}$ \\
\hline Boichiche & $8,788,500$ & $20,310,475$ & $29,098,975$ & $111,713 €$ \\
Goungel & $47,091,000$ & $181,662,045$ & $228,753,045$ & $878,199 €$ \\
Oum Lellé & $85,048,500$ & $288,052,800$ & $373,101,300$ & $1,432,362 €$ \\
Chlim & $9,111,450$ & $31,619,060$ & $40,730,510$ & $156,367 €$ \\
Sawana & $6,289,950$ & $15,544,485$ & $21,834,435$ & $83,824 €$ \\
Tamchekett & 975,000 & $30,082,500$ & $31,057,500$ & $119,232 €$ \\
Tali & $66,814,500$ & $241,540,555$ & $308,355,055$ & $1,183,797 €$ \\
\hline
\end{tabular}

Also included in this section are the following items:

- Firewood (dead wood collected for household fuel)

- Charcoal (widely used on improved stoves for tea-making)

- Construction wood (Acacia nilotica wood is the favoured construction wood in the region due to its large size and strength)

- Bricks (the banco or clay base of the wetlands is used to make sun-dried bricks for construction)

The socio-economic survey asked a random sample of 20 respondents per wetland how much forest products and wild foods they collected for home use or for resale over a one-year period (Table 8). The results are a conservative estimate due to the slight under-representation of the Haratine (Black Moors) community in the questionnaire, given their likely greater reliance on botanical resources (Dunford 2003).

The quantities recorded can be converted into monetary values based on market prices in Aioun in 1999/2000 (Table 8). It should be noted that some respondents in each sample do not collect forestry products and that this is reflected in the average amount collected per person.

\section{Valuing botanical and other natural resources}

The maximum number of fields per wetland is used to represent the number of families using the wetland on a regular basis. ${ }^{10}$ As a general rule, each family owns one flood recession field in a wetland and lives in this field during the growing season when the majority of botanical resources are available and harvested. By multiplying the number of families by the average revenue per person (based on the sample of 20), a conservative value can be given for each wetland's botanical resources (Table 9).

\section{The value of a multiple-use wetland}

An indication of the total value of a multiple-use wetland resources can be calculated from data presented in the preceding sections on:

- Flood recession production of sorghum

- Vegetable production

- Pastoral production

- Botanical and natural resources

Table 10 demonstrates the higher value of pastoral production compared to arable agriculture. Revenue

Table 8 Quantity and value of forestry products, wild foods and natural resources collected by 20 people (Note that this is the total amount collected by 20 people per wetland in a one-year period) at the seven case study wetlands (1999 market prices)

\begin{tabular}{|c|c|c|c|c|c|c|c|c|c|c|c|}
\hline Wetland & Gum arab & $\mathrm{Az}$ & Jib jib & Wild rice & Firewood & Charcoal & Construct wood & Banco & Salaha & Tilba & Value per wetland \\
\hline Units & $\mathrm{kg}$ & $\mathrm{kg}$ & $\mathrm{kg}$ & $\mathrm{kg}$ & Head-load & $\mathrm{kg}$ & Per log & Brick & $\mathrm{kg}$ & $\mathrm{kg}$ & UM \\
\hline Unit value UM & 300 & 80 & 60 & 100 & 150 & 14 & 300 & 4 & 25 & 180 & \\
\hline \multicolumn{12}{|c|}{ Total quantity collected by 20 people per year (kg) } \\
\hline Chlim & 314 & 2,300 & 1,325 & 50 & 2,394 & 2,700 & 207 & 1,530 & 432 & 128 & 861,660 \\
\hline Goungel & 184 & 50 & 1,362 & 0 & 728 & 1,300 & 20 & 1,000 & 432 & 0 & 289,120 \\
\hline Tali & 508 & 104 & 1,083 & 0 & 2,704 & 0 & 200 & 6,000 & 70 & 0 & 717,050 \\
\hline Boichiche & 452 & 2,550 & 1,888 & 0 & 3,408 & 2,300 & 652 & 8,840 & 276 & 0 & $1,234,140$ \\
\hline Tamchekett & 0 & 800 & 1,124 & 0 & 1,902 & 50 & 92 & 1,800 & 332 & 14 & 527,860 \\
\hline Sawana & 728 & 3,400 & 444 & 20 & 1,872 & 1,700 & 112 & 3,000 & 32 & 28 & 875,080 \\
\hline Oum Lellé & 280 & 1,000 & 0 & 0 & 832 & 1,900 & 240 & 5,240 & 0 & 0 & 408,360 \\
\hline
\end{tabular}


Table 9 The value of botanical and natural resources (as described in Table 8) per wetland based on the number of families regularly using the wetland (based on 1999 market prices)

\begin{tabular}{|c|c|c|c|c|}
\hline Wetland & Number of families $^{a}$ & Average revenue/person UM & Total value of botanical resources UM & Total value of botanical resources, Euro $(€)$ \\
\hline Chlim & 75 & 43,083 & $3,231,225$ & 12,405 \\
\hline Sawana & 700 & 43,754 & $30,627,800$ & 117,582 \\
\hline Tali & 200 & 35,853 & $7,170,600$ & 27,528 \\
\hline Boichiche & 60 & 61,707 & $3,702,420$ & 14,214 \\
\hline Goungel & 300 & 14,456 & $4,336,800$ & 16,649 \\
\hline Tamchekett & 588 & 26,393 & $15,519,084$ & 59,579 \\
\hline
\end{tabular}

${ }^{a}$ The number of families is based on the maximum number of fields per wetland in all cases except Tamchekett. As there are no fields at Tamchekett, the population of the town is used. Tamchekett has a population of approximately 3,000 (Leffler 1995), which equates to 588 families based on a household size of 5.1 (United Nations 1995)

from botanical resources is generally ignored by development agencies in their appraisal of natural resource management as they are difficult to value. It is an unseen yet critical source of income, which becomes particularly important in drought years (Dunford 2003).

\section{Economic valuation of single-use systems}

The transformation of wetlands into intensive agricultural systems requires inputs. The level of input required depends on the ecology, topography, hydrology and pedology of the wetland. Shallow wetlands in minor depressions (called gâats in local nomenclature) require minimal transformation, as water levels recede at a rate that allows successful cultivation. Deeper, forested wetlands (tamourts) require substantial inputs to make them suitable for agriculture, as they need to be cleared and then levelled to improve and regulate drainage.

Fencing is considered a prerequisite for all intensively farmed areas to reduce the risks of damage to crops from wandering animals. Barbed wire fencing is costly, and research has shown it to be uneconomic as an investment in the context of eastern Mauritania, as production can rarely pay off the cost of investment before the fence becomes obsolete (Ronco et al. 1999). Finally, investment in fertilisers, pesticides, ploughs and improved seed varieties is required to maximise production. These inputs are costly and beyond the scope of the small-scale farmers currently practising extensive low-input agriculture.

The cost of developing the case study wetlands for agriculture is not limited to input costs. The opportunity costs inherent in the existing multiple-use system must also be accounted for to give a replacement cost for the wetland. The replacement cost of a wetland converted from a multiple-use system to a single-use flood recession agricultural system is based on the loss of pastoral resources, wild foods and medicinal plants, construction materials and biodiversity. In this section, the costs of replacing a wetland as a pastoral resource will be calculated and reference will be made to the loss of revenue from the collection of forestry products, wild foods and other botanical and natural resources.

\section{The replacement cost of pastoral resources}

The loss of wetland resources to the pastoral sector is assessed by calculating the costs of well construction and labour needed for water extraction. The loss of a watering place also leads to a large fall in pastoral productivity, as the surrounding area can offer as much as 11 to 22 thousand tonnes of dry matter which become inaccessible when there is no place to water herds (OECD/CILSS 1987). The loss of dry season pasture due to the conversion of a wetland is difficult to calculate due to variations in the volume of biomass from year to

Table 10 Total production from the seven case study wetlands in 1999/2000 - multiple-use systems (1999 market value) UM

\begin{tabular}{llllll}
\hline Wetland & Sorghum production $^{\text {a }}$ & Vegetable production & Pastoral resources & Botanical resources & Total value UM \\
\hline Chlim & 269,100 & 23,600 & $40,730,510$ & $3,231,225$ & $44,254,435$ \\
Goungel & $3,516,240$ & 235,000 & $228,753,045$ & $4,336,800$ & $236,841,085$ \\
Tali & 79,040 & 162,400 & $308,355,055$ & $7,170,600$ & $315,767,095$ \\
Boichiche & 365,560 & 30,000 & $29,098,975$ & $3,702,420$ & $33,196,955$ \\
Tamchekett & 0 & 61,000 & $31,057,500$ & $15,519,084$ & $46,637,584$ \\
Sawana & $52,243,425$ & 0 & $21,834,435$ & $30,627,800$ & $104,705,660$ \\
Oum Lellé & 0 & 0 & $373,101,300$ & Unknown $^{\text {b }}$ & $373,101,300$ \\
\hline
\end{tabular}

${ }^{\mathrm{a}}$ Flood recession production only; ${ }^{\mathrm{b}}$ no value for botanical resources is included for Oum Lellé as the total number of resource users is unknown 
year. Instead, the cost of replacing the wetland with wells, in order to allow the exploitation of the surrounding pastureland, is calculated.

\section{Replacing surface water with wells}

The surface water available in wetland depressions assures supply to almost $100 \%$ of domestic animal herds during the wet season (July to October) and $50 \%$ of herds during the cold season (November to February). Once developed for agriculture, animals have no access or reduced access to this surface water and wells are needed to replace them. ${ }^{11}$

The number of animals that can drink at a well in a day has been calculated by the OECD/CILSS (1987) and the figures are shown in Table 11. The 30 1/day/TLU consumption figures are adopted as average yearly figures although actual consumption can be higher in the dry season (March to June) (Stoddart et al. 1975). Tropical livestock units (TLUs) are used to aggregate livestock numbers of different species. The equivalents adopted in this study are those used by international agencies such as the Overseas Development Institute (ODI), the Food and Agriculture Organisation (FAO), the World Bank and the European Union (Jahnke 1982; LEAD 2002).

By converting the numbers of animals counted in the study wetlands into TLU, the number of wells needed to replace each wetland can be calculated. The maximum monthly mean is used to signify the highest number of wells needed to replace the wetland. It should be borne in mind that annual variations in wetland volume have an effect on livestock numbers, but as 1999/2000 was an exceptionally wet year, the figures can be taken to represent the maximum number of wells required. The number of wells needed to water the maximum numbers of animals counted at the wetlands in 1999/2000 is calculated based on a median flow rate of $40 \mathrm{~m}^{3} /$ day (Table 12). It should be noted that well construction is not feasible in all areas in eastern Mauritania due to the extreme depth of the water table. In this case, there would be no alternative to surface water, and the value of the wetland rises accordingly.

\section{Labour costs of water extraction}

While animals can help themselves to the water from a wetland, wells demand that water be extracted to meet

Table 11 Numbers of animals that can be watered at a well in a day (OECD/CILSS 1987)

\begin{tabular}{lll}
\hline Rate of flow $\left(\mathrm{m}^{3} /\right.$ day $)$ & $\begin{array}{l}\text { Number of animals per } \\
\text { day }(20 \mathrm{I} / \mathrm{TLU} / \text { day })\end{array}$ & $\begin{array}{l}\text { Number of animals per } \\
\text { day }(30 \mathrm{I} / \mathrm{TLU} / \text { day })\end{array}$ \\
\hline 30 & 1,500 & 1,000 \\
40 & 2,000 & 1,334 \\
50 & 2,500 & 1,667 \\
\hline
\end{tabular}

TLU equivalents: cow (0.7), camel (1), sheep (0.1), goat (0.1) (LEAD 2002)
Table 12 The cost of replacing the wetlands with wells based on flow rates of $40 \mathrm{~m}^{3}$

\begin{tabular}{lllll}
\hline Wetland & $\begin{array}{l}\text { Number of wells } \\
\left(40 \mathrm{~m}^{3} / \text { day }\right)\end{array}$ & $\begin{array}{l}\text { Cost per well } \\
(€)(\text { Euro })^{\mathrm{a}}\end{array}$ & $\begin{array}{l}\text { Total cost } \\
(\mathrm{UM})\end{array}$ & $\begin{array}{l}\text { Total cost } \\
(€)(\text { Euro })^{\mathrm{b}}\end{array}$ \\
\hline Goungel & 7 & 40,000 & $72,934,400$ & 280,000 \\
Oum Lellé & 12 & 40,000 & $125,030,400$ & 480,000 \\
Sawana & 1 & 40,000 & $10,419,200$ & 40,000 \\
Chlim & 1 & 40,000 & $10,419,200$ & 40,000 \\
Tali & 11 & 40,000 & $114,644,200$ & 440,000 \\
Tamchekett & 2 & 40,000 & $20,838,400$ & 80,000 \\
Boichiche & 3 & 40,000 & $31,257,600$ & 120,000 \\
\hline
\end{tabular}

Based on a study carried out in Mauritania in 1999/200 by the KFW (2000);

b2002 conversion rates

the needs of the herd and this implies a labour cost. A single herder in eastern Mauritania can water 60 to 70 cows per day ${ }^{12}$ (Dunford 2000; Diagana 2002). Since 60 to 70 cattle is equal to 42 to 49 TLUs, ratios of herders to livestock can be calculated on the basis of TLU. The monthly wage for pulling water for 60 to 70 cattle is $8,000 \mathrm{UM}$, and an average of 65 cattle or 46 TLUs per herder is adopted in this study.

Mean monthly TLU is used to calculate the labour needed to extract water from wells during a time period equivalent to that where the animals normally drink at wetlands. Average monthly values from 1999/2000 to 2000/2001 are used to estimate labour costs. Any missing values were replaced by a mean value. The annual cost of extracting water from wells for a similar quantity of animals over an equivalent time period to that recorded at the wetlands in 1999/2000 and 2000/2001 is presented in Table 13.

The total first-year replacement cost of the wetlands based on pastoral watering costs is presented in Table 14 . Oum Lellé and Tali have the highest replacement costs in terms of pastoral resources. Costs in later years would depend on the maintenance and depreciation costs of

Table 13 The annual labour costs of extracting water from wells to replace the case study wetlands (based on wages in 1999)

\begin{tabular}{lll}
\hline Wetland & $\begin{array}{l}\text { Number of monthly herders' } \\
\text { salaries to extract water } \\
(8,000 \mathrm{UM} / \text { month) }\end{array}$ & $\begin{array}{l}\text { Annual cost of water } \\
\text { extraction (UM) }\end{array}$ \\
\hline Goungel & 865 & $6,920,646$ \\
Oum Lellé & 1,012 & $8,095,748$ \\
Sawana & 144 & $1,155,718$ \\
Chlim & 220 & $1,758,238$ \\
Tali & 1,413 & $11,304,322$ \\
Tamchekett & 283 & $2,266,022$ \\
Boichiche & 179 & $1,430,184$ \\
\hline
\end{tabular}


Table 14 First-year replacement cost of the case study wetlands as pastoral resources (based on costs in 1999)

\begin{tabular}{lllll}
\hline Wetland & Cost of well construction (UM) & Labour costs of water extraction (UM) & Total cost (UM) & Total cost (€) (Euro) \\
\hline Goungel & $72,934,400$ & $6,920,646$ & $79,855,046$ & 306,569 \\
Oum Lellé & $125,030,400$ & $8,095,748$ & $133,126,148$ & 511,081 \\
Sawana & $10,419,200$ & $1,155,718$ & $11,574,918$ & 44,437 \\
Chlim & $10,419,200$ & $1,758,238$ & $12,177,438$ & 46,750 \\
Tali & $114,644,200$ & $11,304,322$ & $125,948,522$ & 483,525 \\
Tamchekett & $20,838,400$ & $2,266,022$ & $23,104,422$ & 88,699 \\
Boichiche & $31,257,600$ & $1,430,184$ & $32,687,784$ & 125,491 \\
Total cost & & & $418,474,278$ & $1,606,552$ \\
\hline
\end{tabular}

the wells (capital assets) and the recurrent costs of labour.

\section{Opportunity costs}

Once converted to single-use systems, botanical resources are lost as natural vegetation is cleared and the land is drained for agriculture. The resulting loss of habitat has negative impacts on migrating water birds and resident mammals and reptiles, many of which are rare (Shine 2002). In addition, the wetland ceases to fill ecosystem functions, such as water table recharge and sediment accumulation.

In addition to these factors, the comparative labour demands of multiple- and single-use systems need to be considered. Arable farming is more labour intensive than herding with three to seven people needed to cultivate a hectare of land (Ronco et al. 1999). While these inputs are seasonal and only through the growing season, the labour associated with herding is distributed over an entire year. A single herder can look after 100 camels and even higher numbers of sheep. A camel herder's wage is 52,000 UM/year and a shepherd 67,400 UM/year (1998/ 1999 prices; McCracken 2000), while a hectare of land costs between 225,000 and 375,000 UM per year in labour (150 days of growing season $\times$ three to five labourers per hectare $\times 500 \mathrm{UM} /$ day). The extra labour cost required by a single-use agricultural system would constitute a considerable cost to the local communities and/or a draw on labour away from livestock rearing.

The calculation of the full extent of opportunity costs lost in the transformation of wetlands to single-use agricultural systems is beyond the scope of this study, so emphasis is put on the most significant costs, those to livestock rearing.

\section{The value of single-use systems}

The replacement costs presented here for the conversion of multiple-use systems to single-use systems are based on substituting the pastoral resources provided by the wetlands and the opportunity costs (e.g. the loss of botanical resources). Table 15 shows the first-year replacement cost of the seven case study wetlands if converted to single-use agricultural systems.

In order for the pastoral replacement costs presented in Table 14 to be put in context, capital investment costs and revenue from intensive production need to be taken into account. Capital investment costs refer to the levelling, draining and fencing wetlands. Yearly inputs of equipment and products such as pesticides and fertilisers are also needed. Yields under the new system could be as low as those currently produced by the wetlands (Table 16), in line with the regional average of $0.63 \mathrm{t} / \mathrm{ha}$, or as much as $0.8 \mathrm{t} / \mathrm{ha}$, the yields expected by the World Bank agronomists for Goungel (PGRNP/MDRE 1999). Although this project went ahead and Tamourt Goungel was fenced, no data are available on the yields achieved under the new system (hence, we continue to rely on the estimates used at the start of the project). What we do know is that conflict between pastoralists and the settled farming community was an issue and that access rights had to be negotiated to address the tensions over access to the wetland resources (Wabnitz 2007; GRDR 2011).

Figures for potential production can be calculated based on the cultivation of maximum wetland area as recorded in 1999/2000 under these three yield scenarios. It should be noted that this wetland area is an absolute maximum based on the above average rainfall. In reality, production can only be expected one year in every two or three, and yields will not be uniform across the wetland due to micro-scale changes in pedology and drainage.

Even allowing for the continuation of some pastoral production and a modest collection of botanical resources, the figures presented for the highest yielding scenario fall below those for current production illustrated in Table 10 and reflected in the final column of Table 16. This makes the rationale for wetland conversion to single-use systems difficult to justify. To explore this paradox in more detail, production from Tamourt Goungel under the traditional multi-use system will be compared to the expected yields under the intensive single-use system proposed by the World Bank Projet de 
Table 15 First-year replacement cost (UM) of converting multiple-use wetlands to single-use agricultural systems (based on 1999 market prices)

\begin{tabular}{lllll}
\hline Wetland & Well construction (UM) & Annual labour (UM) & Loss of botanic resources/year (UM) & Total replacement cost (UM) $^{\mathrm{a}}$ \\
\hline Goungel & $72,934,400$ & $6,920,646$ & $4,336,800$ & $84,191,846$ \\
Oum Lellé & $125,030,400$ & $8,095,748$ & Unknown & $133,126,148$ \\
Sawana & $10,419,200$ & $1,155,718$ & $30,627,800$ & $42,202,718$ \\
Chlim & $10,419,200$ & $1,758,238$ & $3,231,225$ & $15,408,663$ \\
Tali & $114,644,200$ & $11,304,322$ & $7,170,600$ & $133,119,122$ \\
Tamchekett & $20,838,400$ & $2,266,022$ & $15,519,084$ & $38,623,506$ \\
Boichiche & $31,257,600$ & $1,430,184$ & $3,702,420$ & $36,390,204$ \\
\hline
\end{tabular}

${ }^{\mathrm{a} E x c l u d i n g}$ opportunity costs based on wetland functions, biodiversity and changes in labour demands

Gestion des Ressources Naturelles en Zone Pluviale (PGRNP/MDRE 1999).

\section{Direct economic comparison - multiple-use and single-use systems}

The capital costs of converting Tamourt Goungel to a single-use agricultural system were calculated by the World Bank Project prior to investment (PGRNP/MDRE 1999). Using these estimates and the replacement costs calculated in Table 14, a total value for the conversion of Tamourt Goungel from a multiple-use system to a single-use system is calculated (Table 17). These costs (capital and replacement) can then be compared to the production possible from the improved intensive system based on three possible scenarios (Table 19).

The total cost of converting Goungel to a single-use system was 436,781 Euro (113,772,638 UM). This includes one-off costs, such as levelling and draining the wetland and well construction; however, additional costs would be accrued annually (Table 17). Fencing requires maintenance at $10 \%$ of the capital cost per year (Ronco et al. 1999), and agricultural inputs such as pesticides and fertilisers would also need to be added annually. The labour required to extract water from wells for animal herds is also an annual cost. The loss of revenue from botanical resources also represents an annual opportunity cost (Table 18). The combination of these annual costs adds up to a total of 69,584 Euro per year $(18,125,238 \mathrm{UM})$.

The aim of the investment was to increase agricultural productivity and improve the livelihoods of those who have been reliant on the wetland resources. It must be asked, however, if production from this intensive cropping system justified the level of investment needed.

Production from the proposed 700 ha of agricultural land (PGRNP/MDRE 1999) is calculated based on actual yields recorded in 1999/2000 (0.39 t/ha), on average yields for the region $(0.63 \mathrm{t} / \mathrm{ha})$ and on yields predicted by the project planners $(0.8 \mathrm{t} / \mathrm{ha})$. The revenue from these three scenarios is presented in Table 19.

Based on these production figures, it would take between three and six years to pay back the investment costs and the first year's recurrent costs (Table 17). Annual costs (Table 18) would also have to be taken into consideration and, as their cost is in excess of the annual production under scenario 1 , there would be no return on investment when yields average $0.39 \mathrm{t} / \mathrm{ha}$. The rate of repayment is based on the unlikely scenario that there is optimal rainfall every year. In reality, repayment would take considerably longer as production can only be expected one year in every two or three, due to high levels of rainfall variability (interviews by the author with

Table 16 Maximum possible revenue from single-use agricultural systems based on maximum flooded area and three production scenarios (at 1999 market prices)

\begin{tabular}{lllll}
\hline Wetland & $\begin{array}{l}\text { Scenario 1 - UM value of } \\
\text { actual yield/ha in 1999/2000 }\end{array}$ & $\begin{array}{l}\text { Scenario 2 - UM value based on } \\
\text { regional average yield of 0.63 t/ha }\end{array}$ & $\begin{array}{l}\text { Scenario 3 - UM value based } \\
\text { on projected yield of 0.8 t/ha }\end{array}$ & $\begin{array}{l}\text { Total value UM under multi-use } \\
\text { system (from Table 10) }\end{array}$ \\
\hline Goungel & $17,745,000$ & $28,665,000$ & $36,400,000$ & $44,254,435$ \\
Sawana & $91,399,100$ & $34,193,250$ & $43,420,000$ & $236,841,085$ \\
Tali & $19,088,160$ & $39,557,700$ & $50,232,000$ & $315,767,095$ \\
Chlim & $10,871,640$ & $24,815,700$ & $31,512,000$ & $33,196,955$ \\
Boichiche & $1,909,440$ & $8,353,800$ & $10,608,000$ & $46,637,584$ \\
Tamchekett & N/A & $7,534,800$ & $9,568,000$ & $104,705,660$ \\
Oum Lellé & N/A & $8,804,250$ & $11,180,000$ & $373,101,300$ \\
\hline
\end{tabular}

Based on cultivation of the total wetland area using the yields recorded in 1999/2000 (Table 3), the regional average of 0.63 t/ha (Bureau Statistiques Agricoles 1999) and the projected yields at Tamourt Goungel after development by project PGRNP (PGRNP/MDRE 1999) 
Table 17 The total capital and replacement costs (UM) of converting Tamourt Goungel to a single-use system (1999 market prices)

\begin{tabular}{|c|c|c|c|c|c|}
\hline $\begin{array}{l}\text { Levelling and } \\
\text { drainage }^{a}\end{array}$ & Fencing $^{a}$ & $\begin{array}{l}\text { Agri inputs } \\
\text { including tools }\end{array}$ & $\begin{array}{l}\text { Replacement of } \\
\text { pastoral resources }\end{array}$ & $\begin{array}{l}\text { Loss of botanical } \\
\text { resources }\end{array}$ & $\begin{array}{l}\text { Total cost of } \\
\text { conversion }\end{array}$ \\
\hline $2,772,000$ & $10,750,000$ & $10,898,000$ & $79,855,046$ & $9,497,592$ & $113,772,638$ \\
\hline
\end{tabular}

${ }^{a}$ From PGRNP/MDRE (1999) (fencing excludes maintenance costs; agricultural inputs include one year's supply of fertilisers, pesticides and seeds plus equipment and tools); ${ }^{b}$ based on well construction costs and one year's labour; ' based on one year's revenue calculated by method 2

farmers at the case study wetlands). In short, the system created by outside investment is unrealistic, of low productivity and highly vulnerable to rainfall fluctuations (Table 20).

\section{Comparison of multiple and single-use management systems}

The rural sector accounted for $21 \%$ of Mauritania's GDP in 1999, of which $70 \%$ was from the livestockrearing sector (MEMAU-AGRO 1999). By 2014, agriculture's share of GDP had fallen to $16.9 \%$ (CIA 2015). This could reflect a decline in agricultural GDP due to drought or rural or urban migration, or it could be due to the increase in national revenue from the mining sector, reducing agriculture's overall share. In 1998, 90 \% of livestock rearing was transhumant, dependent on mobility and access to common-pool resources such as wetlands (MDRE/GTZ 1998). Although the numbers of nomadic herders continue to decline in Mauritania, ${ }^{13}$ the numbers remain significant nationally and livelihoods, incomes and employment from extensive livestock-rearing systems would be in jeopardy if all wetlands were converted to agriculture.

Despite the dominance of mobile livestock rearing in the rural sector, investment and development initiatives in Mauritania continue to focus on arable agriculture (Islamic Development Bank 2011; FAO 2015). There has been little or inadequate effort to support livestock in Mauritania despite its importance in rural economy (Islamic Development Bank 2011). Overall, investment continues to be towards intensive arable agriculture and single rather than multiple-use systems, despite the risks posed by a highly variable climate to production and to biodiversity (Brouwer et al. 2014).

Wetlands are considered to be unexploited resources by the government and development agencies, which aim to develop agriculture and settle the population in a zone or terroir (Mullié et al. 1998). By settling populations in a zone and privatising agricultural holdings, development agencies aim to reproduce intensive, western agricultural systems. Unfortunately, these well-intentioned attempts to relieve poverty and improve livelihoods fail to take into account the performance of existing management systems and their ability to cope with high levels of climatic variability. The importance of diversified livelihood strategies and mobility in surviving in an unpredictable environment are all too often ignored.

It is clear that the multiple-use management system generates much greater annual revenues with less exposure to risk than the estimated expected from the singleuse system (Table 20). The differences in revenue are so great that the logic of proposing single-use systems as a development initiative seems flawed. Nevertheless, intensive agricultural systems continue to be promoted in Mauritania and across the Sahel (Brouwer et al. 2014). The reasons for this would seem to stem from the fact that experts tend to transplant methods and approaches from Europe and other parts of West Africa without studying the environmental and social conditions prevailing in eastern Mauritania. This study is the first to measure the production and value of multiple-use systems in Mauritania, and, in the absence of this data, development agencies will continue to make ill-informed decisions on development interventions.

\section{Conclusions}

Production in the northern Sahel is directly linked to rainfall, and rainfall is sporadic, unpredictable and variable in space and in time (Mazzucato and Niemeijer 2000). The Intergovernmental Panel on Climate Change (IPCC 2014) finds that weather in the Sahel will continue to be variable with high confidence that temperatures will increase and low confidence that there will be changes to precipitation levels (IPCC 2014). In order to improve their chances of survival in these variable and unpredictable conditions, Sahelian pastoral communities have based their livelihoods on mobility, flexibility and diversified livelihood strategies (Ellis and Swift 1988; Niamir-Fuller 1999; Krätli and Schareika 2010). Key resources crucial to all members of society are maintained as common-pool resources, regulated by a set of customary rules or social norms. These elements are the basis of the multiple-use management systems employed in the wetlands of eastern Mauritania and which have

Table 18 Additional annual costs involved in converting Goungel to a single-use system (1999 market prices)

\begin{tabular}{llll}
\hline Fencing maintenance & Agri inputs excluding tools ${ }^{a}$ & Water extraction from wells & Loss botanical revenue \\
\hline $1,075,000$ UM & 632,000 UM & $6,920,646$ UM & $9,497,592$ UM \\
\hline
\end{tabular}

${ }^{\mathrm{a}}$ Improved varieties of seeds, pesticides and fertilisers for one year (PGRNP/MDRE 1999) 
Table 19 Potential annual production from intensive agriculture in Goungel based on three yield scenarios (based on 1999 market prices)

\begin{tabular}{lllllll}
\hline Total area cultivated & $0.39 \mathrm{t} / \mathrm{ha}$ & Revenue 1 (UM) & $0.63 \mathrm{t} / \mathrm{ha}$ & Revenue 2 (UM) & 0.8 t/ha & Revenue 3 (UM) \\
\hline 700 ha & 273 & $17,745,000$ & 441 & $28,665,000$ & 560 & $36,400,000$ \\
\hline
\end{tabular}

1 tonne sorghum $=65,000 \mathrm{UM}$

proved resilient in the face of variable rainfall. It is important to learn from these practices so that efforts to increase production and address food insecurity do not risk undermining existing livelihoods.

Development is all too often based on the presumption that inputs can create outputs. The data presented in this paper have shown that despite investing over 24 million UM ( $>92,000$ Euro based on 2002 conversion rates) in developing a wetland for agriculture, production from the new system could never equal the production and replacement costs of the existing multiple-use system. Even if optimal yields could be achieved in some years, there would be other years with zero production due to below-average rainfall. Wetland soils are low in organic matter and badly drained, so annual investment in artificial fertilisers and regular tilling of the soil would be required.

Meanwhile, pastoralist systems have developed to exploit micro-differences in water and grazing availability. Pastoralism actively exploits asymmetric distribution of resources - it does not seek uniformity (Behnke et al. 1993; von Wehrden et al. 2012; Krätli and Schareika 2010). Mobile herders maximise feeding quality and as a result their herd health and productivity, through mobility, targeting different types of forage at different times of year. For example, the forage associated with wetland soils is different in nutrient content to the grasses that grow on the dominant sandy soils - herders know this and actively seek these grasses out for their herds (Krätli and Schareika 2010). Ensuring continued open access to wetlands as sources of water as well as nutrients and minerals is critical for productive and resilient pastoral systems. In this way, multiple-use systems are critical to providing greater flexibility for Sahelian communities, allowing diversified livelihood strategies as well as specialisation and the effective use of local and indigenous knowledge.

The comparison of multiple-use and single-use systems has shown the superior performance of multiple-use systems in Sahelian conditions. So why are governments and development projects insisting on promoting intensive agricultural systems? One reason stems from a mind-set of experts who only know about equilibrium environments, in which climatic conditions are predictable and factors other than rainfall have measurable effects on production. Conversely, capital investment and agricultural impacts have no impact on production in non-equilibrium systems if there is inadequate rainfall (Ellis and Swift 1988; Behnke et al. 1993; von Wehrden et al. 2012). The failure to understand pastoralism as an intelligent system that maximises production in uncertain environments means that investment is not made to strengthen and support this system of natural resource management (Behnke et al. 1993; Niamir-Fuller 1999; von Wehrden et al. 2012; Krätli and Schareika 2010). Likewise, the 'command and control' approach to policymaking that seeks to regulate all areas of a system can actually undermine the system's capacity to work (Krätli and Schareika 2010) - as is the case when ephemeral wetlands are managed under an equilibrium model.

Secondly, government bodies, NGOs and international aid agencies have failed to recognise multiple-use systems, let alone calculate their value (Painter et al. 1994; Adger and Luttrell 2000; Lund 2000; Hesse and MacGregor 2009). This study provides the first economic assessment of the traditional use of wetlands in eastern Mauritania, providing the information necessary to make decisions on development alternatives for the future.

It must also be borne in mind that development projects tend to work with settled communities and, while they may make every effort to ensure the effective participation of these communities in decision-making, project officials often fail to see the myriad of other resource users who depend equally on the natural resources of the area. This leads to distorted views of development priorities and can lead to inequitable outcomes that place key resources in the exclusive ownership of settled communities, to the exclusion of others, including pastoralists. More powerful settled communities often embrace the privatisation of key resources, such as wetlands, as they gain priority access to those resources, while continuing to have access to

Table 20 Comparisons of annual revenue from Goungel under multiple-use and single-use systems (based on 1999 market prices)

\begin{tabular}{|c|c|c|c|}
\hline Multiple-use system - 1999/2000 production ${ }^{\text {a }}$ & Single-use system - revenue $1^{\mathrm{b}}$ & Single-use system - revenue $2^{\mathrm{b}}$ & Single-use system - revenue $3^{b}$ \\
\hline $236,527,739$ UM & $17,745,000$ UM & $28,665,000$ UM & $36,400,000$ UM \\
\hline $908,046 €$ & $68,124 €$ & $110,047 €$ & $139,742 €$ \\
\hline
\end{tabular}

${ }^{\mathrm{a}}$ From Table 10; ${ }^{\mathrm{b}}$ from Table 19. These figures are for sorghum only. There will also be some added revenue from pastoral production and botanical resources 
other wetlands while on transhumance (Blench 1998; Shine 2002; Roe et al. 2009). As a result, development projects that fail to recognise the multiple users and uses of key natural resources risk increasing inequality and social instability.

Experience from Mauritania's Sahelian neighbours indicates that the drive to develop and privatise commonpool resources, such as wetlands, will lead to conflict arising from confusion over laws and competition for valuable resources (Banzhaf et al. 2000; UNEP 2011). Conversely, studies of other wetland pastoral resources in Africa have revealed similar results: that the traditional and informal use of pastoral resources is often more profitable and more resilient in the face of climate change than the alternative systems being promoted by governments and aid agencies (Hesse and MacGregor 2006; Behnke and Kerven 2013; Krätli et al. 2013).

Multiple-use management as practised in Mauritania has resulted in wetland ecosystems being capable of maintaining local livelihoods and preserving biodiversity (Adger and Luttrell 2000). Over 20,000 waterbirds used Sawana in the winter of $1999 / 2000$, while the wetland created over 104 million UM $(399,263 €)$ in revenue for local families. This is significant in a country where $50 \%$ of the population lived below the poverty line at the time of the study (World Bank 1997) and where poverty rates continue to hover around $23 \%$ (UNICEF 2013). ${ }^{14}$ At the same time as playing this important socio-economic role, Sawana was also a globally significant wetland in terms of biodiversity, based on the criteria for Ramsar status of hosting a population of 20,000 or more waterbirds. It is not just waterbirds that give such biological significance to the wetlands; it is also the vegetation, fish, reptiles and wild mammals that depend on them and the wise management of these resources for their survival. Intensive, single-use systems do not offer the same opportunities for people and biodiversity to co-exist harmoniously as the traditional multiple-use systems.

Development based on multiple-use systems offers a more food-secure, productive and ecologically sustainable future for Sahelian communities than investment in single-use agricultural systems. Unfortunately, the dominant response to food insecurity in Mauritania continues to focus on increasing cereal production with little attention given to livestock production (FAO 2015). Given the challenges associated with climate change and competition for natural resources in a time of population growth, the inherent resilience and productivity of multi-use systems warrants further study and greater integration into development planning. The key to this approach must be a recognition of pastoralism as a system geared to maximise the production of economic value from dryland environments and not merely as a coping strategy to deal with uncertainty (Ellis and Swift
1988; Behnke et al. 1993; Niamir-Fuller 1999; von Wehrden et al. 2012; Krätli and Schareika 2010).

As uncertainty and variability increase with climate change, pastoralism needs to be invested in as a strategic way of using dryland resources, including ephemeral wetlands, so that the adaptive capacity of the system can be maximised. Of all the natural resource-based land uses in the drylands, pastoralism functions best within the context of wide rainfall variability and unpredictability (Nassef et al. 2009). As a result, pastoralism is a logical climate change adaptation strategy, maximising the flexibility associated with mobility and with cobenefits in terms of carbon sequestration from wellmanaged rangelands and wetlands. The capacity of pastoralists to exploit these strategies is constrained by ill-conceived programmes that seek to impose equilibrium models on non-equilibrium systems and which contribute to maladaptation and inequitable development outcomes. Valuing key pastoralist resources in drylands, including ephemeral wetlands, is an important step in recognising the larger contribution pastoralist systems make to food security and climate action in dryland ecosystems.

\section{Endnotes}

${ }^{1}$ Wet season - July to October; cold season - November to February; dry season - March to June

${ }^{2}$ Note that Tamourt Goungel was fenced as a result of the PGRNP project and later, passages for livestock herds were negotiated (Wabnitz 2007). The project is no longer operational, and the status of the fences is unknown.

${ }^{3}$ Flood recession agriculture is practised in the wetland depressions with planting taking place as the water level recedes. Rain-fed agriculture on the other hand is practised in the wetland catchment and relies on rainfall to provide the soil moisture necessary for plant growth.

${ }^{4}$ Due to the sensitive nature of this information, a local technician interviewed the producers.

${ }^{5}$ The number of people using the resources of a wetland varies throughout the year, and with large numbers of occasional visitors, it is impossible to give an accurate number of users per wetland. The total population of the east of the country was estimated at over 528,000 people by the last published census in 1988 (Hodh Ech Chargui 212,203; Hodh El Gharbi - 159,296; Assaba - 129,162 (ONS 1997)).

${ }^{6}$ Haratine or Black Moor refers to the descendants of freed slaves. White Moors or Beydanes are the ruling caste in Mauritania and have Arab Berber origins.

${ }^{7}$ Project GIRNEM was a natural resource management project operated by the GTZ (German Technical Cooperation, now GIZ). The principal author worked with this project while carrying out her research. 
${ }^{8} \mathrm{UM}=$ Mauritanian Ougiya, 1 Euro was the equivalent of $260.480 \mathrm{UM}$ in June 2002, and these are the conversion rates used throughout the paper. For comparative purposes, $€ 1$ was the equivalent of $326.689 \mathrm{UM}$ in January 2016.

${ }^{9} \mathrm{~A}$ more complete data set is available for $1999 / 2000$ than 2000/2001; hence, this is the year used for these calculations.

${ }^{10} \mathrm{~A}$ range of settled and to a lesser extent nomadic communities collect botanical resources at the wetlands. The number of resource users varies throughout the year, and from year to year, according to seasonal movements, rainfall and resource availability. Using fields as a basis for calculation gives a conservative estimate of the population involved in the activity.

${ }^{11}$ After this study was completed, access routes for livestock were negotiated for livestock herds (Wabnitz 2007) which may allow them access crop residues outside the growing season.

${ }^{12}$ Cattle drink daily during the dry season, as do goats and sheep, while camels drink every four to five days. During the wet season, cattle drink every two days, sheep and goats every two to three days and camels every five to six days (Stoddart et al. 1975).

${ }^{13}$ Although the availability of demographic and statistical data on mobile pastoralists is improving, it is impossible to document with any accuracy any transformations in the numbers of these populations over the last half century (Randall 2015).

${ }^{14}$ Twenty-three percent of the population below the international poverty line of US\$1.25 per day (\%) 2007 to 2011 .

\section{Acknowledgments}

This study could not have been carried out without the commitment and effort of numerous people. These include Mohamed Jiddou, agricultural technician at the Aioun delegation of the Ministry of Agriculture and Rural Development, for his part in collecting data on agricultural productivity. Those living near and using the resources of Sawana, Oum Lellé, Goungel, Chlim, Tamchekett and Boichiche gave their time and shared information and their experience openly and generously. Particular thanks go to those from each community who undertook to count and record livestock numbers on a weekly basis. The staff from Project GIRNEM provided support and advice, and special thanks go to Mohamed Moctar (Cherif) N'Diaye, Mohamed Vall Ould Lelle and Stephen McCracken. Our gratitude goes to the World Bank PGRNP project for sharing their planning documents and technical reports with us.

Thanks to Claire Guyer and John Pollard of the University of Ulster, Coleraine, Northern Ireland, for the assistance with earlier drafts, and to Camilla Toulmin of IIED, for her assistance with this updated paper.

\section{Authors' contributions}

TS carried out all aspects of the study except the collection and analysis of the socio-economic survy led by $\mathrm{BD}$ which included data on forestry products, wild foods and biological and other natural resources. As noted in the methodology field staff from Project GIRENM and local enumerators assisted with the collection of data in the field. Both authors read and approved the final manuscript.

\section{Competing interests}

The authors declare that they have no competing interests.

\section{Author details}

${ }^{1}$ Environment and Development Consultant, 127 The Meadows, Belgooly, Co., Cork, Ireland. ${ }^{2}$ United States Agency for International Development, USAID, Washington, DC, USA.

Received: 20 January 2016 Accepted: 3 May 2016

Published online: 24 May 2016

\section{References}

Adams, W.M. 1992. Wasting the rain: Rivers, people and planning in Africa. London: Earthscan Publications Ltd.

Adger, W.N., and C. Luttrell. 2000. Property rights and the utilization of wetlands. Ecological Economics 35: 75-89.

African Union. 2003. Comprehensive Africa Agriculture Development Programme (CAADP). New Partnership for Africa's Development (NEPAD).

African Union. 2010. Policy framework for pastoralism in Africa: Securing, protecting and improving the lives, livelihoods and rights of pastoralist communities. Retrieved from http://rea.au.int/en/sites/default/files/ Policy\%20Framework\%20for\%20Pastoralism.pdf?q=dp/rea/sites/default/files/ Policy\%20Framework\%20for\%20Pastoralism.pdf. Accessed 8th January 2016.

Banzhaf, M., B. Drabo, and H. Grell. 2000. Du conflit au consensus. Securing the commons, 36. London: IIED.

Behnke, R., and C. Kerven. 2013. Counting the costs: Replacing pastoralism with irrigated agriculture in the Awash valley, north-eastern Ethiopia. IIED Climate Change Working Paper No. 4, March 2013.

Behnke, R., I. Scoones, and C. Kerven (eds.). 1993. Range ecology at disequilibrium: New models of natural variability and pastoral adaptation in African Savannas. London: ODI.

Blench, R. 1998. Resource conflict in semi-arid Africa. An essay and annotated biography. London: ODI.

Bognounou, O., J.M. Ouadba, and J.N. Poda. 1994. Les aspects globaux des zones humides du Burkina Faso. Zones Humides du Burkina Faso. L. Sally, M. Kouda and N. Beaumond. Gland, Switzerland, IUCN: 11-28.

Breman, H., and C.T. de Wit. 1983. Rangeland productivity and exploitation in the Sahel. Science 221(4618): 1341-1347.

Brouwer, J., Hamadou Amadou Abdoul Kaderb, and T. Sommerhalter. 2014. Wetlands help maintain wetland and dryland biodiversity in the Sahel, but that role is under threat: An example from 80 years of changes at Lake Tabalak in Niger. Biodiversity. 15(2-3): 2014. Drylands Special Issue.

Agricoles, Bureau Statistiques. 1999. Statistiques agricoles: Hodh El Gharbi. Aioun, Mauritania: SSP/DRAP/MDRE.

CIA. 2015. The world fact book. Mauritania. 2015. Washington DC: Central Intelligence Agency. Retrieved on the 8th January 2016 from https://www. cia.gov/library/publications/the-world-factbook/geos/mr.html.

Dahl, G., and A. Hjort. 1976. Having herds: Pastoral herd growth and household economy. Stockholm: Department of Social Anthropology, University of Stockholm.

Diagana, C. 2002. Etude des pratiques d'accès et d'utilisation des ressources des zones humides de l'Est Mauritanien : cas de Tali, de Sawana/Oum Lellé, de Bougari et de Boichiche. Faculté d'Agronomie. CRESA Niamey: DESS, Université de Abdou Moumouni.

Dunford, B. 2000. Socio-economic uses of Eastern Mauritanian wetlands, 15. Nouakchott: Project GIRNEM, GTZ.

Dunford, B. 2003. The shifting sands of authority and ambiguity in natural resource management in eastern Mauritania. Department of Sociology: East Lansing, Michigan State University.

Ellis, J.E., and D.M. Swift. 1988. Stability for African pastoral ecosystems: Alternate paradigms and implications for development. Journal of Rangeland Management 41: 450-459.

FAO - Food and Agriculture Organisation. 2015. Mauritania and FAO. FAO. Accessed online 16 March 2016. http://www.fao.org/documents/card/en/c/ 2236f2ba-98fb-413c-acdb-cb3d4054a9b1/.

GIRNEM. 1999. Mission d'appui à la planification de la quatrième phase du Projet GIRNEM. Nouakchott, Mauritania: Coopération Technique Allemande (GTZ) \& Ministère du Développement Rural et de l'Environnement (MDRE). 18 + 12 annexes.

GRDR. 2011. Atlas du Sud-Est Mauritanien. Dynamiques Rurales. Retrieved 8th January 2016 from http://www.grdr.org/IMG/pdf/Atlas_def_BD_v6.pdf.

Hesse, C., and J. MacGregor. 2006. Pastoralism: drylands' invisible asset? Developing a framework for assessing the value of pastoralism in East Africa, Issue paper no. 142. London: IIED. 
Hesse, C., and J. MacGregor. 2009. Arid waste? Reassessing the value of dryland pastoralism. International Insituiture of Envrionment and Development (IIED), June 2009.

Hesse, C., and B. Thébaud. 2006. Will pastoral legislation disempower pastoralists in the Sahel? Indigenous Affairs 1(06): 14-23.

IPCC. 2014. Fifth assessment report. Intergovernmental panel on climate change. Chapter 22 Africa, 1202-1265.

Islamic Development Bank. 2011. Member Country Partnership Strategy of the IDB Group for Mauritania. 2011-2015G/1432 - 1436H.

Jahnke, H.E. 1982. Livestock production systems and livestock development in tropical Africa. Kiel: Kieler Wissenschaftsverlag Vauk.

KFW. 2000. E-mail communication with details of Projet Hydrolique Villageois. June 2000.

Krätli, S. \& Schareika N. 2010. Living off Uncertainty. The Intelligent Animal Production of Dryland Pastoralists. European Journal of Development Research 22(5): 605-622.

Krätli, S., C. Huelsebusch, S. Brooks, and B. Kaufmann. 2013. Pastoralism: A critica asset for food security under global climate change. Animal Frontiers 3(1): 42-50. January 2013.

LEAD Livestock Environment and Development. 2002. Tropical livestock units (TLU). LEAD, FAO, Rome

Leffler, S. 1995. Actualisation de la Base de Données Régional: Hodh El Gharbi. Aioun, Mauritania, PRADER: Programme d'Appui au Développement Régional de la Wilaya du Hodh El Gharbi.

Leriche, A. 1953. Phytothérapie maure : de quelque plantes et produits végétaux utilisés en thérapeutique. Mélanges Ethnologiques, IFAN 23: 267-306.

Lund, C. 2000. African land tenure: Questioning basic assumptions, 25. London: IIED Drylands Programme.

Mazzucato, V., and D. Niemeijer. 2000. Overestimating land degradation, underestimating farmers in the Sahel, 22. London: Drylands Issue Paper, IIED.

McCracken, S. 2000. Final report: GIRNEM/PHV. Nouakcott: GTZ. 38 + appendices. MDRE/BDPA-SCETAGRI. 1992. Le betail et la viande en Mauritanie:

Commercialisation interieure et exterieure, situation actuelle et perspectives. Nouakchott, MDRE.

MDRE/GTZ. 1998. Orientations pour l'Elaboration du Code Pastoral en République Islamique de Mauritanie. Nouakchott: Ministère du Développement Rural et de l'Environnement

MEMAU-AGRO. 1999. Statistiques Agricoles. Nouakchott: MDRE.

Mullié, W.C., and J. Brouwer. 1994. Les zones humides du Niger: écologie, éxotoxicologie et importance pour les oiseaux d'eau afro-tropicaux et paléarctiques. Atelier sur les zones humides du Niger. Comptes rendus d'un atelier à la Tapoa, parc du "W", Niger, du 2 au 5 novembre 1994. P. Kristensen. Niamey, Niger, IUCN- Niger: 27-52.

Mullié, W., J. Brouwer, S.F. Codjo, and R. Decae. 1998. Small isolated wetlands in the central Sahel: A resource shared between people and waterbirds, Proceedings of Workshop 2 of the 2nd International Conference on Wetlands and Development, 8-14 November 1998, Dakar, Senegal, Wetlands International, Wageningen, The Netherlands.

Nassef, M., S. Anderson, and C. Hesse. 2009. Pastoralism and climate change: Enabling adaptive capacity. London: ODI.

Niamir-Fuller, M. (ed.). 1999. Managing mobility in African rangelands: The legitimization of transhumance. London: Intermediate Technology Publications.

Nickel, H. 2001. Biodiversität Mauritaniens, Kommentierte Liste zu den reell und potenziell in Mauritanien vorkommenden Vertebraten, mit Ausnahme der Aves (Vögel). Nouakchott, Mauritania: Project GIRNEM, GTZ.

OECD/CILSS. 1987. Analyse des conditions de l'élevage et propositions de politiques et de programmes. Mali: Bamako.

ONS, Office National de la Statistique. 1995. Agrégats de la Comptabilité Nationale et Indicateurs Socio-Economiques. Nouakchott: ONS.

ONS, Office National de la Statistique. 1997. Recensement Général de la Populations et de l'Habitat, 1988, 51. Nouakchott: ONS, Ministere du Plan. V: Analysis.

ould Abderrezagh, M. 1999. Guide de présentation des espèces végétales Mauritaniennes, 30. Nouakchott, Mauritania: MDRE/PGRNP.

ould Cheikh, A.D. 1986. Les Problemes Actuels du Nomadisme Sahelien: Le cas de la Mauritanie. Nouakchott: CILSS/Institut du Sahel, Etudes et Travaux de I'USED, No. 4.

Painter, T., Sumberg, J. and Price, T. 1994. Your Terroir and my 'Action Space': Implications of differentiation, mobility and diversification for the approche terroir in Sahelian West Africa. Africa 64(4): 447-464.

PGRNP/MDRE. 1999. Diagnostique du Terroir Villageois de Goungel, 31. Nouakchott: Projet de Gestion des Ressources Naturelles en Zone Pluviale (PGRNP).
Randall, S. 2015. Where have all the nomads gone? Fifty years of statistical and demographic invisibilities of African mobile pastoralists. Pastoralism. Retrieved on the 8th January from http://www.pastoralismjournal.com/ content/5/1/22.

Roe, D., F. Nelson, and C. Sandbrook (eds.). 2009. Community management of natural resources in Africa: Impacts, experience and future decisions. Natural Resources Issues No. 18.. London: IIED.

Ronco, D., T. Shine, and S. McCracken. 1999. Barbed wire enclosures in southeastern Mauritania: A cost/benefit analysis, 18. Aïoun, Mauritania: GIRNEM/GTZ.

Shine, T. 2001. Mission d'identification d'un projet régional de gestion durable des zones humides au Mali, Mauritanie et au Burkina Faso, 17. Eschborn, Germany: GTZ.

Shine, T. 2002. An integrated investigation of the ephemeral wetlands of eastern Mauritania and recommendations for management. PhD thesis, School of Biological and Environmental Science, University of Ulster, Northern Ireland

Stoddart, L.A., A.D. Smith, and T.W. Box. 1975. Range management. New York: McGraw-Hill Book Company.

UNEP. 2011. Climate change, conflict and migration in the Sahel.. United Nations Environment Programme.

UNICEF. 2013. State of the World's Children 2013. http://www.unicef.org/ infobycountry/mauritania_statistics.html Accessed 23 May 2016.

United Nations. 1995. The worlds' women 1995: Trends and statistics. New York, USA: United Nations.

Van Lancker, C.J. 1999. Abbatoirs de Nouakchott: Organisation et Systeme de Gestion. Rapport Provisoire Nouakchott, MDRE/SAN/ETEC Engineering.

von Maydell, H.-J. 1992. Arbres et Arbustes du Sahel: leurs caractéristiques et leurs utilisations. Weikersheim, Germany: Verlag Josef Margraf.

von Wehrden, H., J. Hanspach, P. Kaczensky, J. Fischer, and K. Wesche. 2012. Global assessment for the non-equilibrieum concept in rangelands. Ecological Applications 22(2): 393-399.

Wabnitz, Hans-Werner. 2007. The code pastoral of the Islamic Republic of Mauritania Return to the sources: Revival of traditional nomads' rights to common property resources. Retrieved from http://ssrn.com/abstract=906985, 8th January 2016.

Wetlands International. 2015. Wetland solutions for people and nature. Strategic intent 2015-2025. The Netherlands: Wageningen.

World Bank. 1997. Mauritania - country assistance strategy. Washington: World Bank. IDA/R97-60/1: 20

World Bank. 2013. Mauritania - country partnership strategy (FY2014-2016). Washington: World Bank. Report No: 75030-MR.

\section{Submit your manuscript to a SpringerOpen ${ }^{\circ}$ journal and benefit from:}

- Convenient online submission

- Rigorous peer review

- Immediate publication on acceptance

- Open access: articles freely available online

- High visibility within the field

- Retaining the copyright to your article

Submit your next manuscript at $>$ springeropen.com 